\title{
Toxicity in man due to stain removers containing 1,2-dichloropropane
}

\author{
C POZZI, ${ }^{1}$ P MARAI, ${ }^{1}$ R PONTI, ${ }^{1}$ C DELL'ORO, ${ }^{1}$ C SALA, ${ }^{2}$ S ZEDDA ${ }^{2}$ AND \\ F LOCATELLI
}

From the Nephrology and Dialysis Unit, ${ }^{1}$ and Occupational Health Unit, ${ }^{2}$ Hospital of Lecco, Italy

ABSTRACT There are reports that 1,2-dichloropropane, a constituent of many commercial solvents and stain removers in Italy, has caused severe liver damage and, sometimes, acute renal failure. Between 1980 and 1983 three cases of 1,2-dichloropropane intoxication ( 1 by ingestion, 2 by inhalation) were observed. Clinical features included severe liver damage, acute renal failure (2 patients), haemolytic anaemia, and disseminated intravascular coagulation. The most surprising features were haemolytic anaemia and disseminated intravascular coagulation which have not been reported before. The clinical picture was similar despite different modes of exposure.

1,2-Dichloropropane (1,2-D), or propylene dichloride $\left(\mathrm{CH}_{2} \mathrm{Cl} . \mathrm{CHCl} . \mathrm{CH}_{3}\right)$, is a colourless and volatile (vapour pressure $35 \mathrm{~mm} \mathrm{Hg}$ at $70^{\circ} \mathrm{F}$ ) liquid widely used in commercial solvents and stain removers. Its toxicity in animals has been known since $1946,{ }^{1}$ whereas in man it was reported for the first time only in 1968 when liver damage was found in six patients, one of whom had acute renal failure. ${ }^{2-4}$ In these cases 1,2-D was ingested. More recently, Parker and his coworkers ${ }^{5}$ studied the toxicity of 1,2-D by inhalation in mice and rats and concluded that only lethal concentrations can produce appreciable injury to the lung, liver, and kidney, whereas mutiple sublethal exposure resulted only in slight toxic effects.

Since 1,2-D is a good solvent, less expensive than other chlorinated compounds, it is widely used in Italy, even at high concentrations, in manufacturing different makes of commercial solvents and Trielina (a commercial preparation used to remove stains from clothes). A study carried out in Italy ${ }^{6}$ showed that in all commercial stain removers sold for domestic use 1,2-D was present at high concentrations (70-98\%). Moreover, the industrial use of 1,2-D has also increased, especially in the paint industry. The increase in its domestic and industrial use and Trielina sniffing by young people ${ }^{7-10}$ has increased the risk of toxic exposure to 1,2-D.

We describe three cases of intoxication with acute hepatic, haematological, and renal ( 2 patients) damage caused by inhaling or ingesting 1,2-D. One

Received 25 April 1985 Accepted 1 July 1985 case has been previously reported. ${ }^{11}$

Gas chromatographic examination of Trielina in case 1 showed almost only 1,2-D, and in case 2 showed $98 \%$ of $1,2-\mathrm{D}$ (the remaining $2 \%$ was trichloroethylene and dichloroethane); in case 3 gas chromatographic examination of the solvent showed $60 \%$ of $1,2-\mathrm{D}$ (the remaining $40 \%$ consisted of acetone, isobutyl alcohol, and n-butyl acetate).

\section{Case 1}

A 28 year old man admitted to hospital in April 1980 a few hours after the accidental ingestion of a stain remover sold as Trielina. On admission haemoglobin, haematocrit, renal and liver function, and coagulation test results were normal. Two days later he developed renal failure (serum creatinine $380 \cdot 12$ $\mu \mathrm{mol} / 1(4.3 \mathrm{mg} / 100 \mathrm{ml})$, creatinine clearance 20 $\mathrm{ml} / \mathrm{min}$ blood urea nitrogen $7 \cdot 13 \mathrm{mmol} / \mathrm{l}(43 \mathrm{mg} / 100$ $\mathrm{ml})$ ), and liver damage (total bilirubin $63.27 \mu \mathrm{mol} / \mathrm{l}$ (3.70 mg\%) of which $41.04(2.40)$ was conjugated, AST $1850 \mathrm{U} / \mathrm{l}$, ALT $2300 \mathrm{U} / \mathrm{l}$, prothrombin activity $25 \%$ of normal control). Slight disseminated intravascular coagulation was also found (fibrinogen degradation products $10-40 \mu \mathrm{g} / \mathrm{ml}$, plasma fibrinogen $196 \mathrm{mg} / 100 \mathrm{ml}$ ). Forced diuresis was carried out, after which renal function improved: on the fourth day serum creatinine concentration was $155.28 \mu \mathrm{mol} / \mathrm{l}$ $(1.70 \%)$ and creatinine clearance $110 \mathrm{ml} / \mathrm{min}$; liver damage persisted (total bilirubin $280.44 \mu \mathrm{mol} / 1$ ( $3 \cdot 70$ $\mathrm{mg} / 100 \mathrm{ml})$ of which $186.39(2.40)$ was conjugated, AST $1510 \mathrm{U} / 1$, ALT $1880 \mathrm{U} / \mathrm{l}$, prothrombin activity $44 \%$ of normal control, and increased hepatic LDH 
isoenzymes), and haemolytic anaemia appeared HCT $34.6 \%$, unconjugated bilirubin $90.63 \mu \mathrm{mol} / 1 \quad(5.3$ $\mathrm{mg} / 100 \mathrm{ml}$ ). On the seventh day the patient died of septic shock.

\section{Case 2}

A 20 year old girl complained of vomiting, abdominal pain, widespread ecchymoses, haematuria, and metrorrhagia in February 1982. A week later the symptoms regressed, and laboratory findings showed: total bilirubin $89.43 \mu \mathrm{mol} / 1(5.23 \mathrm{mg} / 100 \mathrm{ml})$ of which 25.99 (1.52) was conjugated, AST 96 U/1, ALT $804 \mathrm{U} / \mathrm{l}$, and $\mathrm{HbsAg}$ negative. No further clinical investigations were performed.

In November 1982 she was admitted with oliguria, epistaxis, haematuria, metrorrhagia, and periorbital and conjunctival haemorrhages. Two days before admission she had vomited and had had abdominal pain, followed by fever, with facial oedema and erythema. Laboratory findings showed severe renal failure (serum creatinine $743.4 \mu \mathrm{mol} / 1(8.4 \mathrm{mg} / 100$ $\mathrm{ml})$, BUN $34.19 \mathrm{mmol} / \mathrm{l}(206 \mathrm{mg} / 100 \mathrm{ml}))$, acute liver damage (AST $660 \mathrm{U} / \mathrm{l}$, ALT $1730 \mathrm{U} / \mathrm{l}$, total bilirubin $193.23 \mu \mathrm{mol} / 1(11.30 \mathrm{mg} / 100 \mathrm{ml})$ of which 109.44 $(6.40)$ was conjugated, prothrombin activity $16 \%$ of normal control)), haemolytic anaemia (HCT $21.6 \%$, plasma haptoglobin undetectable), and disseminated intravascular coagulation (platelet count $10000 / \mathrm{mm}^{3}$, fibrinogen degradation products over $40 \mu \mathrm{mol} / \mathrm{ml}$, plasma fibrinogen $100 \mathrm{mg} / 100 \mathrm{ml}$, partial thromboplastin time $44 \mathrm{sec}$ ). C3 serum concentration was decreased $(28 \mathrm{mg} / 100 \mathrm{ml})$ and $\mathrm{C} 4$ was undetectable in serum. A peripheral blood smear did not show fragmented red cells. The Coombs test, A and B hepatitis markers, antinuclear antibodies, and WidalWright and leptospira test results were negative. The patient was treated with transfusions of fresh blood (500-1200 $\mathrm{ml}$ for two consecutive days) and plasma (450-1200 $\mathrm{ml}$ a day for seven days), and underwent four haemodiafiltration sessions. Oligoanuria reversed after eight days. Renal biopsy findings were consistent with acute tubular necrosis. Three weeks after admission the patient was discharged with complete recovery of her renal and liver function and normal coagulation tests. Serum C3, C4, and haptoglobin concentrations were normal.

After much questioning the patient admitted that since January 1982 she had been sniffing Trielina every night before sleeping to sedate herself and evade reality. In fact she considered Trielina as effective as other stupefacients, cheap, and easily available. After the first acute episode in February she stopped sniffing but started again in November. During the course of one night she repeated the operation four times: the symptoms of the second episode appeared the next morning.

\section{Case 3}

A 55 year old woman suffering from membranoproliferative glomerulonephritis and on home haemodialysis three times a week since March 1980 was admitted in April 1983 with abdominal pain. Laboratory tests showed severe liver failure (AST and ALT over $6000 \mathrm{U} / 1, \mathrm{LDH}$ about $\times 12000 \mathrm{U} / 1$, increased hepatic fractions 4 and 5 and prothrombin activity $32 \%$ of normal control). Haemolytic anaemia was also found, shown by decreased plasma haptoglobin, increased erythrocytic LDH isoenzymes, increased unconjugated bilirubin 51.3 $\mu \mathrm{mol} / 1(3 \mathrm{mg} / 100 \mathrm{ml})$, total bilirubin $61.56 \mu \mathrm{mol} / \mathrm{l}(3.6$ $\mathrm{mg} / 100 \mathrm{ml})$, and reticulocytosis $(3 \cdot 4 \%)$. Haematocrit remained at the previous low level $(22 \%)$. The osmotic resistance of the red cells was reduced, with $23 \%$ haemolysis at $0.60 \mathrm{NaCl}$ concentration (normal values $0 \cdot 5-2 \%$ ). Slight disseminated intravascular coagulation was also found (platelet count $74000 / \mathrm{mm}^{3}$, fibrinogen degradation products over $40 \mu \mathrm{g} / \mathrm{ml}$, plasma fibrinogen $202 \mathrm{mg} / 100 \mathrm{ml}$ ). We did not perform blood transfusion and haemodialysis was continued. The patient's condition rapidly improved. A week after admission haemolytic activity disappeared (serum haptoglobin $195 \mathrm{mg} / 100 \mathrm{ml}$, erythrocytic LDH isoenzymes decreased, total bilirubin 14.70 $\mu \mathrm{mol} / 1(0.86 \mathrm{mg} \%))$ as did the disseminated intravascular coagulation (platelet count $151000 / \mathrm{mm}^{3}$, fibrinogen degradation products less than $10 \mu \mathrm{g} / \mathrm{ml}$, plasma fibrinogen $310 \mathrm{mg} / 100 \mathrm{ml}$ ). The osmotic resistance returned to normal and the liver disease improved (AST 49 U/l, ALT 736 U/1, LDH 500 U/l, prothrombin activity $100 \%$ of normal control). $\mathrm{HbsAg}$ and Widal-Wright test results were negative. Peripheral blood smear did not show fragmented red cells. Biliary and liver echography did not show pathological findings.

The patient disclosed that three days before admission she had spent six hours cleaning her flat using two litres of solvent, during which time she noticed no untoward effects, only a nasty smell. In the afternoon she underwent haemodialysis at home. During the following three days she developed anorexia, abdominal pain, and nocturnal sweating, and was admitted to hospital.

\section{Discussion}

Organic solvent toxicity has been known for many years. Renal and hepatic damage has been described after exposure to some chlorinated aliphatic hydrocarbons ${ }^{2781213} ; 1,2-\mathrm{D}$ toxicity in man is less 
often reported. ${ }^{24}$ In the three cases reported here 1,2-D apparently caused renal and hepatic damage, a haemolytic anaemia, and disseminated intravascular coagulation.

Renal damage-Two patients ( 1 and 2 ) had normal renal function before exposure to 1,2-D; patient 3 was on haemodialysis. Though patient 1 did not undergo renal biopsy the laboratory data and clinical course were consistent with acute tubular necrosis. Renal biopsy was performed on patient 2 , and histological examination showed acute tubular necrosis. Immunofluorèscence and electron microscopy investigations were negative. This is consistent with a direct toxic damage on the renal tubular cells, as suggested by experimental studies. ${ }^{1513}$

Hepatic damage-All three patients showed impairment of liver function. None underwent liver biopsy, but we may presume the presence of centrilobular hepatic necrosis, as observed by some authors in experimental ${ }^{1}$ and clinical ${ }^{48}$ studies. It is interesting that LDH-isoenzymes electrophoresis, performed in patients 1 and 3, showed not only increased hepatic fractions 4 and 5 but also fraction 6 which is usually present only in the spermatic fluid; this fraction disappeared after the recovery of hepatic function.

Haemolytic anaemia-Haemolytic anaemia in 1,2-D intoxication has never been reported either in experimental studies or in man but was present in our patients. The Coombs test results were negative, peripheral smear showed no fragmented red cells, and osmotic resistance was reduced (case 3 ). We think that a direct toxic effect on red blood cells is responsible for the haemolysis.

Disseminated intravascular coagulation, previously unreported, was observed in each of the three patients but was clinically important only in patient 2 .

In conclusion, our patients had acute renal and hepatic injury, haemolytic anaemia, and disseminated intravascular coagulation resulting from exposure to 1,2-D. The clinical picture was similar in all three patients, despite different modes of exposure: ingestion or inhalation. In all cases an interval of more than 24 hours elapsed between exposure to 1,2-D and the onset of symptoms. Since $80-90 \%$ of $1,2-\mathrm{D}$ and its metabolites are eliminated in the expired air, urine, and faeces within 24 hours after exposure, ${ }^{51415}$ we may conclude that when the symptoms appear the analysis of blood, urine, and faeces for the solvent is useless. The wide use of 1,2-D in commercial solvents and Trielina could be a dangerous and unknown source of intoxication because they are commonly found in the home and are sniffed by young people. For this reason greater knowledge about chronic toxicity and more suitable legal measures concerning the use of 1,2-D are required.

\section{References}

${ }^{1}$ Heppel LA, Highman B, Peake EG. Toxicology of 1,2-dichloropropane. J Ind Hyg Toxicol 1948;30:189-91.

${ }^{2}$ Ponticelli C, Imbasciati E, Redaelli B, Salvadeo A. Insufficienza epato-renale acuta da trielina. Lavoro Umano 1968;20:205-12.

${ }^{3}$ Chiappino G, Secchi GC, Descrizione di un caso di intossicazione acuta da ingestione accidentale di 1,2-dichloropropano venduto come trielina. Med Lav 1968;59:334-41.

${ }^{4}$ Secchi GC, Chiappino G, Lotto A, Zurlo N. Composizione chimica attuale delle trieline commerciali e loro effetti tossici. Studio clinico ed enzimologico. Med Lav 1968;59:486-97.

${ }^{5}$ Parker CM, Coate WB, Voelker RW. Subchronic inhalation of 1,3-dichloropropene/1,2-dichloropropane in mice and rats. $J$ Toxicol Environ Health 1982;9:899-910.

${ }^{6}$ Zedda S, Sala C, Pozzi C, Locatelli F. Intossicazione acuta nell'uomo da 1,2-dichloropropano. Bollettino Documenti Sicurezza Igiene Lavoro CEDIS 1984;3:51-7.

${ }^{7}$ Litt IF, Cohen MI. "Danger ... vapour harmful": spot-remove? sniffing. N Engl J Med 1969;281:543-4.

${ }^{8}$ Baerg RD, Kimberg DV. Centrilobular hepatic necrosis and acuteo renal failure in "solvent sniffers." Ann Intern Med" 1970;73:713-20.

${ }^{9}$ Bonnichsen R, Maehly AC. Poisoning by volatile compounds. Chlorinated aliphatic hydrocarbons. J Forensic Sci Soc 1966;11:414-27.

10 James WRL. Fatal addiction to trichloroethylene. Br J Ind Med 1963;20:47-9.

${ }^{11}$ Locatelli F, Pozzi C. Relapsing haemolytic-uraemic syndrome after organic solvent sniffing. Lancet 1983;ii:220.

12 Hardin BL. Carbon tetrachloride poisoning - a review. Industrial Medicine and Surgery 1954;23:93.

${ }^{13}$ Gutch CF, Tomhave WG, Stevens SC. Acute renal failure due to inhalation of trichloroethylene. Ann Intern Med 1965;63:128-35.

${ }^{14}$ Hutson DH, Moss JA, Pickering BA. Excretion and retention of components of the soil fumigant D-D and their metabolites in rat. Food and Cosmetics Toxicology 1971;9:677.

15 Jones AR, Gibson J, 1,2-dichloropropane: metabolism and fate in the rat. Xenobiotica 1980;10:835-46. 